\title{
Typology for flight-to-quality episodes and downside risk measurement
}

\section{Mariya Gubareva \& Maria Rosa Borges}

To cite this article: Mariya Gubareva \& Maria Rosa Borges (2016) Typology for flight-toquality episodes and downside risk measurement, Applied Economics, 48:10, 835-853, DOI: 10.1080/00036846.2015.1088143

To link to this article: http://dx.doi.org/10.1080/00036846.2015.1088143

册 Published online: 18 Sep 2015.

Submit your article to this journal $\pi$

Llll Article views: 139

Q View related articles ¿

View Crossmark data ¿

4 Citing articles: 2 View citing articles ๘ 


\title{
Typology for flight-to-quality episodes and downside risk measurement
}

\author{
Mariya Gubareva (D) ${ }^{\mathrm{a}}$ and Maria Rosa Borges (D)

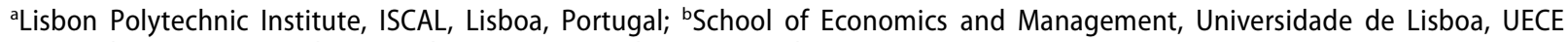 \\ (Research Unit on Complexity and Economics), Lisboa, Portugal
}

\section{ABSTRACT}

We propose a total return-based framework to measure downside risk associated with phenomenon of capital outflows from riskier to safer financial markets. The proposed method consists of three elements: (i) the general definition of the flight-to-quality (FtQ) phenomenon, (ii) the typological classification of the flight-to-quality occurrences for associating them with the phases of the business cycle and (iii) the automated technique to diagnose the time frames and to measure the impact of flight-to-quality on financial instruments. The proposed framework is applied to analyse the global-scale capital inflows/outflows from emerging markets public debt to the US Treasuries and vice versa. The results show that different phases of business cycles and GDP growth rates, including turning points, could be associated with flights-to-quality of different types and causality origins. Addressing downside risk crystallizations in flight-to-quality occurrences, new perspectives of integrated interest rate risk and credit risk management are discussed. For strengthening financial stability, we suggest the use of flight-to-quality windows as scenarios for stress testing, both for banks and financial institutions.

\section{KEYWORDS}

Flight-to-quality; downside risk; financial crisis; emerging markets; US Treasury bonds

JEL CLASSIFICATION F30; G15; G20

\section{Introduction}

The existence of flight-to-quality phenomena in fixed income and stock markets weakens balance sheets of banking and financial institutions and makes them more volatile over the time. This volatility is often associated with capital outflow and other types of perception related pressures. The situation when investors begin to fear the weakness of market participants' balance sheets is also an important issue for the understanding of flight-toquality occurrences when investors rebalance their portfolios towards less risky investments with the objective to preserve wealth rather than generate it. Investors fly from the riskiness of diverse assets to the quality of safe investments. Consequently, this leads to a relative increase in prices of risk-free securities and to a respective decrease in prices of risky instruments. Often, under these circumstances, an increase in prices of safe haven assets and a slide in prices of the riskier securities can strengthen such investors' behaviour further on. Investors continue to withdraw their money from risky investments and fly to the quality of risk-free assets.
The flight-to-quality phenomenon has been attracting considerable scientific interest (Jones 2012; Briere, Chapelle, and Szafarz 2012; Rösch and Kaserer 2013; Pagano and Strother 2013; Psillaki and Eleftheriou 2014; Chabot 2014; Guerrieri and Shimer 2014). In spite of the continuous reappearance of flight-to-quality events along the economic history, the first mention related to these phenomena was made only less than two decades ago by Bernanke, Gertler, and Gilchrist (1996). The authors show that during economic turmoil low-grade firms suffer more decrease in their production and spending than large corporations. Later on, Goyenko and Ukhov (2009) and Naes, Skjeltorp, and Odegaard (2011), analysing the liquidity dynamics of diverse asset classes, alternatively define flight-to-quality events as an increase of investors' preferences for the most liquid securities. Diverse issues of interdependence between flight-to-quality and market liquidity are addressed by Brunnermeier and Pedersen (2009), who, differentiating between market liquidity and funding liquidity, model fragility and liquidity spirals. At the same time, Beber, Brandt, and Kavajecz (2009) try to disentangle a 
flight-to-quality from a flight-to-liquidity. In parallel, Baur and Lucey (2009) and Inci, Li, and McCarthy (2011), examining the correlation between various markets, describe flight-to-quality as a period when the correlation between a chosen pair of markets decreases, while the performance of the riskier market drops. Although varied research has been dedicated to the flight-to-quality phenomena and their economic drivers, there is still a lack of a universal, generally accepted, definition of these episodes. The definitions of the flight-to-quality event used by diverse authors usually depend on the purpose of the respective research (Lei and Wang 2012). These definitions are quite restrictive, as, for instance, in the case of emerging markets flight-to-quality events can be observed while correlation between safe and risky assets performance holds and, in some cases, with increasing prices of risky assets. Thus, additional research in this field remains highly desirable and the creation of a general framework for flight-to-quality analyses is needed.

Our study develops a total return-based framework for flight-to-quality studies focusing on fixedincome securities. Our methodology sheds light on the nature of this type of events and widens the set of approaches available to research these phenomena. First, the proposed definition of flight-to-quality phenomenon is based on the comparison of safe and risky assets performance, instead of analysing differential spreads (Blinder and Zandi 2010; Barkbu et al., 2012) and/or short-run correlations (Bunda, Hamann, and Lall 2009; Inci, Li, and McCarthy 2011). Thus, the presented methodology based on total return-based definition of flight-to-quality goes beyond the differential spread techniques used for fixed-income securities, as it is applicable to all asset classes, and also, in a certain sense, is superior to the correlation approach to measure flights-to-quality which is a relative measure, by its nature.

The proposed measurement technique for identifying and tracking flight-to-quality episodes offers an important insight on the changing relationship between rates of return and credit risk. It helps us to distinguish between different kinds of flights-toquality and could be used for event analysis in other contexts of risk management. An important characteristic of our methodology is the use of total return on assets rather than relative rates of return.
Second, we propose a typological classification of flight-to-quality events, based on the interest rate dynamics and total returns behaviour of safe and risky securities. The type of flight-to-quality event depends on the interest rates of both asset baskets moving up, moving down or one moving up while the other moves down. This typological classification envisages taking into consideration the economic conditions under which a flight-to-quality occurs. We study the macroeconomic dynamics preceding and succeeding flight-to-quality and show that different phases of business cycles and GDP rates behaviour, including turning points, could be associated with flights-to-quality of different types and nature.

The proposed asymmetric threefold typology for flight-to-quality episodes can be operationalized for event analysis in order to correlate different patterns of the flight-to-quality with movements in macroeconomic aggregates. The advantage this offers is twofold. On the one hand, it suggests a superior understanding of the relationship between rate of return and credit risk for use in stress testing or similar balance sheet simulations. On the other hand, it offers a new indicator for changes in cyclical conditions. It is demonstrated that different patterns of the flight-to-quality tend to cluster around different periods of performance in both US and world output growth.

Third, the total return-based technique we apply allows identifying the time frames and the strength of the events, i.e. temporal patterns of observed market volatility. This technique improves the widely applied differential spread-based approaches, which are based on the spread between the yields of bonds, and thus represent a relative measure of the impact of flight-to-quality events, but provide no information about the separate dynamics of safe and risky assets.

To the best of our knowledge, the vast majority of research in this field focus either on what happens within the flight-to-quality event or on its influence on the economy and on the welfare of society (Caballero and Kurlat 2008). We take a different approach of focusing also on what happens before the ignition of a flight-to-quality and after its termination. We compare the performance of risky and safe assets returns prior, within and after the event.

Our proposed total return-based framework is applied to the study of flights-to-quality out of 
risky sovereign emerging market bonds towards the safety of US Treasury bonds over the period from January 1998 to December 2010. Such diagnostic technique not only provides an exact knowledge of the relative asset performance, similar to the differential spread dynamics, but allows investigating in a separate manner the performance of safe and risky assets for a chosen pair of origination-destination domains subjacent to a flight-to-quality under investigation.

Many flights-to-quality do coincide with the ignition of crises and/or financial panics, but still there are quite common cases when they do not result in vicious financial spirals (Gubareva and Borges 2013). So, it is worth understanding the differences between these two situations as it is potentially insightful for early diagnostics of financial disasters. We also demonstrate that the flight-to-quality term covers a wide range of similar but still distinctive events. Those sub-varieties of flight-to-quality could be thought of as flight-from-risk characterized by risk aversion being a primary driver of the capital move; flight-to-safety characterized by a superior performance of safe assets caused by a relative lack of their supply and a wide gamma of mixed origin occurrences.

Our research sheds light on how financial institutions may address hedge strategies against downside risks, related to interdependence of credit risk and interest rate risk. Capturing the interaction between these risks within the flight-to-quality time windows during diverse business cycle phases potentially allows banks and financial institutions to optimize their economic and regulatory capital, thus accelerating economy and augmenting social welfare.

Our findings indicate that the interrelation between interest rate and credit risk differs between expansion and contraction phases of the business cycle. In contraction phases when capital flies from risky to safe assets, credit risk spreads of the former increase and yields of the latter decrease. It was especially so during the recent financial crisis when interest rates dropped and simultaneously the average creditworthiness of debt issuers, being banks, corporates or sovereigns, deteriorated too. Although this situation could appear counterintuitive, the novel contribution of this study is that it is not an exceptional case, but rather common and expectable, that crashes and recessions usually coincide with downward tendency in interest rate dynamics.

Finally, the concept of isolated interest rate risk management ought to be rethought in terms of a downside risk management of jointly considered interest rate and credit risk impacts. Our study urges the re-examination of widely used practices of interest rate risk hedging by pay-fixed receivefloat interest rate swaps (IRS), being usually contracted to mitigate negative outcomes of downtrends in interest rates without due analyses of the macroeconomic conjuncture and interrelations between different types of financial risk.

The rest of the article is organized as follows. Section II presents the proposed working definition of flight-to-quality events and their subsequent typology. Section III describes the methodology for the ex post diagnostics of flight-toquality time frames and their impact on security values. The application for the case of flights between risky sovereign emerging market bonds and the safe US Treasury bonds over the period from 1998 to 2010 and their typological classification are provided in Section IV. Conclusions are presented in Section V.

\section{Definition and typology of flight-to-quality}

Although the work by Mandelbrot and Hudson (2004) serves as a motivational instigation of our work, it is worth stressing that all the components of the framework discussed in this section, such as the proposed definition and the elements of the typological classification, represent our own original contributions. They do not represent adding portions of any already published methodology by any known to us previous author. All the methods presented in this and the following sections are ours and were newly developed in the course of this research.

The first part of our framework is the flight-toquality definition, which is based on the performance of assets measured in terms of total returns.

Definition: A flight-to-quality event is an investment migration from risky to safe assets leading to an underperformance of total returns of risky assets when compared to the total returns of safe assets.

The underperformance of risky assets is usually caused by a sudden drop in risk appetite and 


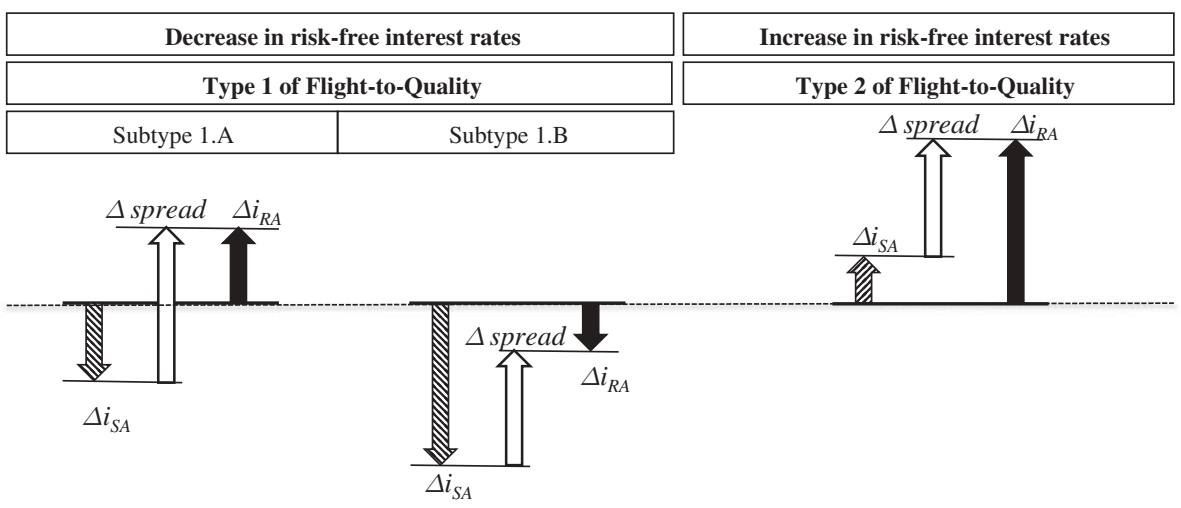

Figure 1. Flight-to-quality typological classification.

increase in risk aversion. Thus, a quantification of the investors' appetite for safe and risky assets becomes potentially insightful for deepening the comprehension of flight-to-quality events.

The second component of our framework is a typological classification of the flight-to-quality events. A two-level classification is proposed, as summarized in Fig. 1.

As can be observed from Fig. 1, this classification is an asymmetric threefold typology. The types of events are defined according to the behaviour of two observable parameters: (i) the dynamics of the riskfree interest rate $\left(\Delta i_{S A}\right)$ and (ii) the dynamics of the risk premium or spread of risky assets over safe assets ( $\Delta$ spread). The type of flight-to-quality itself provides information on both parameters: the sign of the risk-free interest rate change (type 1 versus type 2) and the relative strength of the risk aversion, where the spread is either superior or inferior to the change in the risk-free interest rate (subtype 1A versus subtype $1 \mathrm{~B}$ ).

Type 1 events are those where the yield of safe assets decreases (i.e. the total return on safe assets increases) and is divided into two subtypes - one where the yield of risky assets increases (i.e. the total return on risky assets decreases) and another where the yield of risky assets decreases by less than the yield of safe assets (i.e. the total return on risky assets increases by less than the total return of the safe assets). In both cases, the spread between risky and safe assets increases - but the increase in the spread is greater for any given decrease in the rate of return on safe assets under the first subtype than under the second. Type 2 events are those where the yield of safe assets increases (i.e. the total return decreases) but the yield of risky assets increases by even more (i.e. the total return on risky assets decreases even more than the total return on safe assets). Again, the spread between safer and risky assets increases.

To complete the set of all the possible yield dynamics combinations, it is worth noting that there are three more cases of joint yield (total return) dynamics, which though, by definition, do not correspond to flight-to-quality occurrences and represent three different types of recovery. They are briefly addressed in Tables 1 and 2. All these three cases of recovery correspond to the situation where the yield on safe assets increases and the yield on risky assets decreases (or increases by less). Those are cases where the spread narrows.

An alternative visualization of the proposed typology, i.e. the classification including the non-

Table 1. Flight-to-quality typology: yields dynamics perspective.

\begin{tabular}{|c|c|c|c|}
\hline $\begin{array}{l}\text { Flights-to-quality versus } \\
\text { recoveries }\end{array}$ & & $\begin{array}{l}\text { Flight-to-quality: risky-safe } \\
\text { assets spread rises }\end{array}$ & $\begin{array}{l}\text { Recovery from flight-to- } \\
\text { quality: risky-safe assets } \\
\text { spread falls }\end{array}$ \\
\hline Yields dynamics & & \multicolumn{2}{|c|}{ Yield of risky assets } \\
\hline Yield of safe assets & Falls & $\begin{array}{l}\text { Rises } \rightarrow \text { FtQ subtype } 1 \mathrm{~A} \\
\text { Falls } \rightarrow \text { FtQ subtype } 1 \mathrm{~B}\end{array}$ & Falls $\rightarrow$ recovery type 1 \\
\hline & Rises & Rises $->$ FtQ type 2 & $\begin{array}{l}\text { Rises } \rightarrow \text { recovery subtype } 2 A \\
\text { Falls } \rightarrow>\text { recovery subtype } 2 B\end{array}$ \\
\hline
\end{tabular}


Table 2. Flight-to-quality typology: total returns dynamics perspective.

\begin{tabular}{|c|c|c|c|c|c|}
\hline \multirow{3}{*}{\multicolumn{2}{|c|}{$\begin{array}{l}\text { Flights-to-quality (FtQ) versus anti-FtQ } \\
\text { (recoveries) }\end{array}$}} & \multirow{2}{*}{\multicolumn{2}{|c|}{$\begin{array}{c}\text { Flight-to-quality: risky-safe assets spread rises } \\
\text { Total return on risky assets }\end{array}$}} & \multirow{2}{*}{\multicolumn{2}{|c|}{$\begin{array}{l}\text { Recovery from flight-to-quality: } \\
\text { risky-safe assets spread falls } \\
\text { Total return on risky assets }\end{array}$}} \\
\hline & & & & & \\
\hline & & Falls & Rises & Falls & Rises \\
\hline Total return of safe assets & Rises & Downturn FtQ & Upturn FtQ & No anti-FTQ & Anti-FtQ \\
\hline
\end{tabular}

flight-to-quality occurrences, denominated as recoveries, is presented in Table 1.

As our primary focus is on flights-to-quality, the occurrences of the opposite nature are not discussed here in more detail. We just mention that along these occurrences the spread between safe and risky assets compresses. Since the spread decreases and prices of risky assets improve, this suggests that there is appetite towards holding risky assets across the market as a whole. These occurrences are denominated recoveries (for instance, from a flight-to-quality) in order to emphasize that their patterns are contrarian to patterns of flights-to-quality as for risky assets they represent bullish events, i.e. anti-flights-toquality. Nevertheless, a possibility to desiccate bullish behaviour of risky assets into three types of anti-flight-to-quality patterns represents a challenging research opportunity and deserves being addressed in future works as studying markets in their state of a relative calmness, out of turmoil, could be insightful for uncovering the mechanisms at play during crises and retrocessions. The necessity of such approach to financial markets is acknowledged by Mandelbrot and Hudson (2004).

In respect to the classified above types of flights-to quality, to discuss their economic sense, one can examine yields and rates of return in risky and safe asset classes. The question is how to interpret movements in these rates of return. In each type, we would be interested to ask why returns would move as they do - and what it would mean if safe assets move by more or less than risky assets. For simplicity, we focus on fixed income.

For example, why would returns rise across both safe and risky assets? The answer would probably be a movement from fixed income to other more rewarding asset classes, like equity, etc. We would expect to see this on the upturn in a business cycle. In fact, that is what we find in the type 2 cases and present further on in Fig. 7 dedicated to the application of our approach. Thus, for this type of flightsto-quality we propose the meaningful name Upturn flight-to-quality.

The nature of subtype $1 \mathrm{~B}$ flights-to-quality could be ascribed to growing caution in the market. This is a movement out of highly rewarding but excessively risky assets, as equity, leveraged loans, etc., into traditional fixed income. We should expect to see this at the start of a downturn. In fact, Fig. 6 demonstrates the correctness of our insight presenting the subtype $1 \mathrm{~B}$ flights-to-quality coinciding with turning points when the accentuated slowdown begins. Hence, for this subtype of flight-to-quality we suggest the meaningful name Start-of-the-downturn flight-to-quality.

As the concern for capital preservation gains momentum, we should expect to see movement across fixed income risk classes. This movement will slow the decline in yields on riskier fixed income assets and could even cause them to rise again even as the yield on safe assets is declining. This is a movement from subtype 1B Start-of-the-downturn flight-to-quality to the subtype $1 \mathrm{~A}$ to be redenominated into a Downturn flight-to-quality. It is worth noting that Downturn flight-to-quality is a process originated within the fixed income asset class, while two previously discussed cases are likely to have their cross-asset-classes origins.

Table 2 presents the typology, not only using the suggested above names of the flight-to-quality, but also operating with total return metrics instead of yields dynamics, as discussed earlier.

The typology we propose is a theoretical attempt to deepen the flight-to-quality understanding and to analyse the phenomenon in the context of the economic environment. In the majority of previous research, only subtype $1 \mathrm{~A}$ events are identified and analysed. We argue the importance of correctly identifying the other types of flight-to-quality events as they can provide 
warning signals of upcoming changes in the business cycle. The typology is used to interpret the results obtained from the application of the methodology we describe below.

\section{Flight-to-quality diagnostics}

The third element of our proposed framework is a total return-based automated technique to identify the occurrence of flight-to-quality events, measuring their impact and delimiting the start and end dates (time windows) of their occurrence. The general concept resides in the quantitative difference in the aggregate performance of risky and safe assets. The methodology is defined by the following four steps.

\section{First step}

For each rolling anchor date $(A D)$ of a chosen $n$-day long interval, a set of $n$ different subjacent subintervals is considered; the anchor date is fixed, while the initial dates go from 1 to $n$ days back into the past. Then, the $n$ values of percentage returns of the risky asset total return index (further on referred to as risky assets index) and the respective $n$ values of percentage returns of the safe asset total return index (further on referred to as safe assets index) are computed. Thus, the $n$ different initial dates are employed in the consecutive return calculations using in each turn the same final date, or anchor date. This means that each time after the rolling anchor date $(A D)$ is fixed the algorithm goes by 1-day steps into the past until the chosen $n$-day limit, i.e. the date $A D$ $-n$ is reached. Thus, the first step can be represented by

$$
R_{(A D-k, A D)}^{I_{n d e x}}=\frac{\operatorname{Index}_{(A D)}}{\operatorname{Index}_{(A D-k)}}-1
$$

where Index stands for safe (risky) assets index; $R^{\text {Index }}$ is the return of safe (risky) assets index; $A D$ is an anchor date consecutively assuming all the dates within the analysed historical period; $k$ is a number of days within which the return of the safe (risky) assets index is calculated. Here, $k \in[1, n]$ while $n$ could be thought as the largest analysed flight-to-quality window.

\section{Second step}

The $n$ differences between the returns of safe and risky assets indexes $\left(\Delta R_{k}\right)$ are to be computed by the following formula:

$$
R_{k(A D)}=R_{(A D-k, A D)}^{S}-R_{(A D-k, A D)}^{R}
$$

where $k \in[1, n] . \quad R_{(A D-k, A D)}^{S}$ and $R_{(A D-k, A D)}^{R}$ stay, respectively, for the returns of safe assets and risky assets indexes between the dates $A D-k$ and $A D$.

\section{Third step}

The search for the maximum delta $\left(\Delta R_{(A D)}^{M A X}\right)$ for each anchor date $(A D)$ is performed and the maximum value out of the $n$ values of the return differences between safe and risky assets indexes is identified. This could be written as follows:

$$
\Delta R_{(A D)}^{M A X}=\underset{k=1,2, \ldots, n}{\operatorname{MAX}}\left(\Delta R_{k(A D)}\right)
$$

In parallel, the number of days $(k)$, which corresponds to $\triangle R_{(A D)}^{M A X}$, is stored as $N_{A D}$. It is worth noting that the length of the subinterval $N_{A D}$, which maximizes the difference in returns for each anchor date, is not fixed and varies from one anchor date to the next, and so on. In the fourth step of the algorithm, this number $N_{A D}$ will be used for determining the initial dates of flight-to-quality events.

This procedure is repeated for all dates in the period under analysis, each date, in turn, being defined as an anchor date. For each of the rolling anchor dates, the values of their respective $\triangle R_{(A D)}^{M A X}$ (maximized as a function of the parameter $k$ according to Equation 3) are used to build the respective curve of maximum differences between safe and risky assets index returns. This curve is schematically represented in Fig. 2.

Abscissa of each point of the curve illustrated in Fig. 2 corresponds to the rolling anchor date $(A D)$. In its turn, an ordinate is the maximum difference in returns of safe and risky assets indexes within $n$ subintervals of the $n$-day-long window. The local maxima of the $\triangle R_{(A D)}^{M A X}$ curve, marked by dashed ovals in Fig. 2, are the end dates $(E D)$ of the flightto-quality events. This can be comprehended as follows. Prior to a chosen local maximum date, corresponding to the flight-to-quality end date ( $E D$ in bold) the flight-to-quality impact on the 


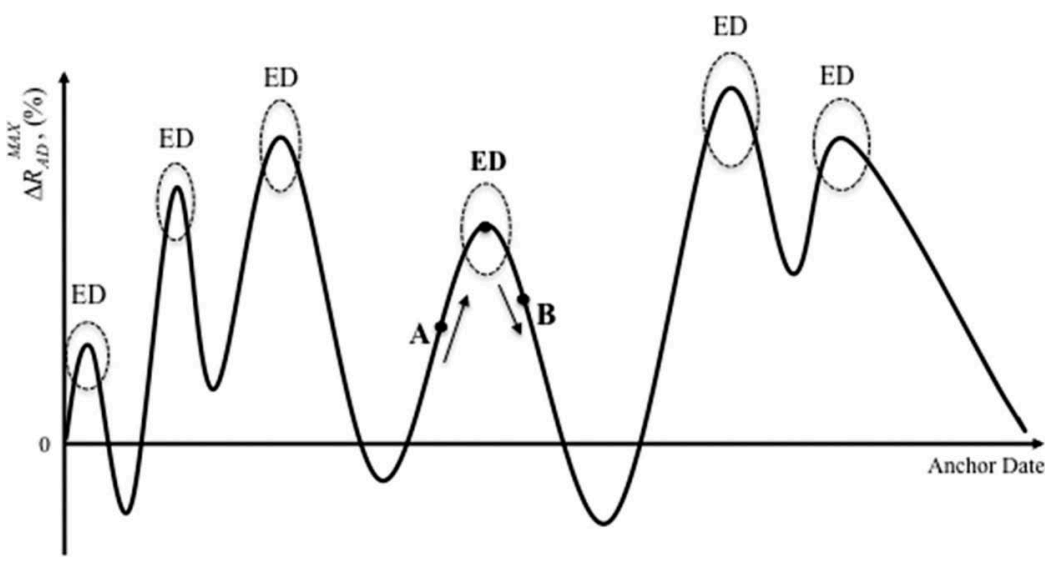

Figure 2. Maximum differences between safe and risky assets total returns in percentage of the initial indexes' values observed $N_{A D}$ days prior to the anchor date $(A D)$.

total returns difference is strengthening with time; see point $\boldsymbol{A}$ in Fig. 2. On the other hand, posterior to the same chosen local maximum date ( $E D$ in bold), the difference in the total returns along the time scale is decaying; see point $\boldsymbol{B}$ in Fig. 2. That is the reason why the local maximums of the $\triangle R_{(A D)}^{M A X}$ curve are considered to determine the end dates $(E D)$ for the preceding them flight-to-quality events. This is what one would expect to observe and what in fact is observed while searching for flight-to-quality end dates $(E D)$.

\section{Fourth step}

For the identified end dates $(E D)$, the difference in returns between safe and risky asset indexes $\left(\triangle R_{(I D, E D)}^{M A X}\right)$ is maximized as a function of the initial date of flight-to-quality (ID), which can be obtained by the following equation:

$$
\Delta R_{(A D)}^{M A X}=\operatorname{MAX}_{k=1,2, \ldots, n}\left(R_{(E D-k, E D)}^{S}-R_{(E D-k, E D)}^{R}\right)
$$

where $I D=E D-k$.

Here, the use of end date $(E D)$ instead of anchor date $(A D)$ means that only the end dates of flight-toquality $(E D)$, identified in the third step of the algorithm, are employed and not all the rolling anchor dates. Using the parameter $N_{A D}$, mentioned in the third step of the algorithm, which is the number of days of a flight-to-quality event, the initial date (ID) is expressed as follows:

$$
I D=E D-N_{E D}
$$

Summarizing, the essence of the algorithm is: first, determining the end date $(E D)$ of the flight-toquality event, which corresponds to the local maximum of the safe and risky total return difference of the considered rolling periods; second, determining the initial date (ID), which corresponds to the maximum difference between safe and risky total returns for the identified flight-to-quality end date $(E D)$. Finally, in the selection process of flight-toquality-like events to be included in the sample, $\triangle R_{(I D, E D)}^{M A X}$ must exceed a predefined hurdle or event impact parameter $(E I P)$. The greater the value of this selection filter criterion, the more impactful are the flights-to-quality identified and the smaller is their number within the period under analysis.

\section{Application}

\section{Data and imposed conditions}

The proposed flight-to-quality identification methodology described in Section III is applied to detect the time windows of flights out of the emerging market fixed income securities described by the J.P. Morgan EMBI-Global index (further on referred as $E M B I)$ to the US Treasury debt issues represented by the UST total return index provided by the iBoxx Ltd (further on referred as ITRROV) in the period from January 1998 to December 2010. The original historical values of the above indexes compiled, respectively, by J.P. Morgan and iBoxx, were extracted through the Thomson Reuters DataStream and the Bloomberg terminals. 
The trial maximum duration of flight-to-quality events $(n)$ is assumed to be 45 working days as the analysed flight-to-quality phenomenon is typically a short-run event, very concentrated in time. For example, Mandelbrot and Hudson (2004) claim that in diverse markets sharp drops and rises in prices occur within very limited and narrowed periods of time which corroborates with our choice of the maximum duration of flights-to-quality. It is worth noticing that sharp price movements are consistent with the proper term flight used to address this phenomenon. Additionally, the spread of the aggregated yield of emerging markets debts over aggregated yield of US Treasury, described by the J.P. Morgan emerging markets sovereign debt spread index is examined. These data were imported from the Bloomberg terminal. As a result, we find that the 45-day period is an appropriate time window for flight-to-quality events.

The EIP, or the hurdle difference between the $E M B I$ and ITRROV, is defined as three different levels, $1 \%, 2 \%$ and $3 \%$. Such limits imposed to the total returns differences are considered to characterize the notion of investment migration and allow for gradual analysis of the complex structure of flightsto-quality.

\section{Internal structure of flights-to-quality}

When analysing flight-to-quality events, by means of the automated technique proposed herein in
Section III to historical data series of the EMBI and ITRROV indexes, it is important to take into account that there are situations when the same initial date (ID) corresponds to different consecutive end dates $\left(E D_{i}\right)$, as it is illustrated by the black arrows in Fig. 3.

Such aggregated flight-to-quality could be decomposed into a set of weaker flights-to-quality. Thus, for each identified end date $\left(E D_{i}\right)$, with the exception of $E D_{1}$, an intermediate initial date $\left(I D_{i}\right)$ lying between $E D_{i-1}$ and $E D_{i}$ should be determined. Consequently, the identified aggregated flight-toquality can be alternatively analysed as if it was composed of four weaker flights-to-quality, as represented in Table 3.

In Table 3, $\Delta$ stands for strength of flight-toquality being the difference between ITRROV and $E M B I$ returns in percentage in respect to the initial date $\left(I D_{i}\right)$ indexes' values. The shadowed cells represent the earliest initial date $\left(I D_{1}\right)$ and the latest end date $\left(E D_{4}\right)$ corresponding to the highest maximum difference in the returns of the ITRROV and $E M B I\left(\Delta R_{(E D)}^{M A X_{-} E M B I_{-} v s_{-} I T R R O V}\right)$.

Table 3. Decomposed flight-to-quality (27 March 2000-22 May 2000).

\begin{tabular}{lccc}
\hline$I D$ & $E D$ & $\Delta(\%)$ & Aggregated (\%) \\
\hline 27 March 2000 & 5 April 2000 & 4.27 & $\wedge$ \\
12 April 2000 & 17 April 2000 & 1.48 & $\wedge$ \\
2 May 2000 & 12 May 2000 & 3.97 & $\wedge$ \\
18 May 2000 & 22 May 2000 & 2.28 & 7.71 \\
\hline
\end{tabular}

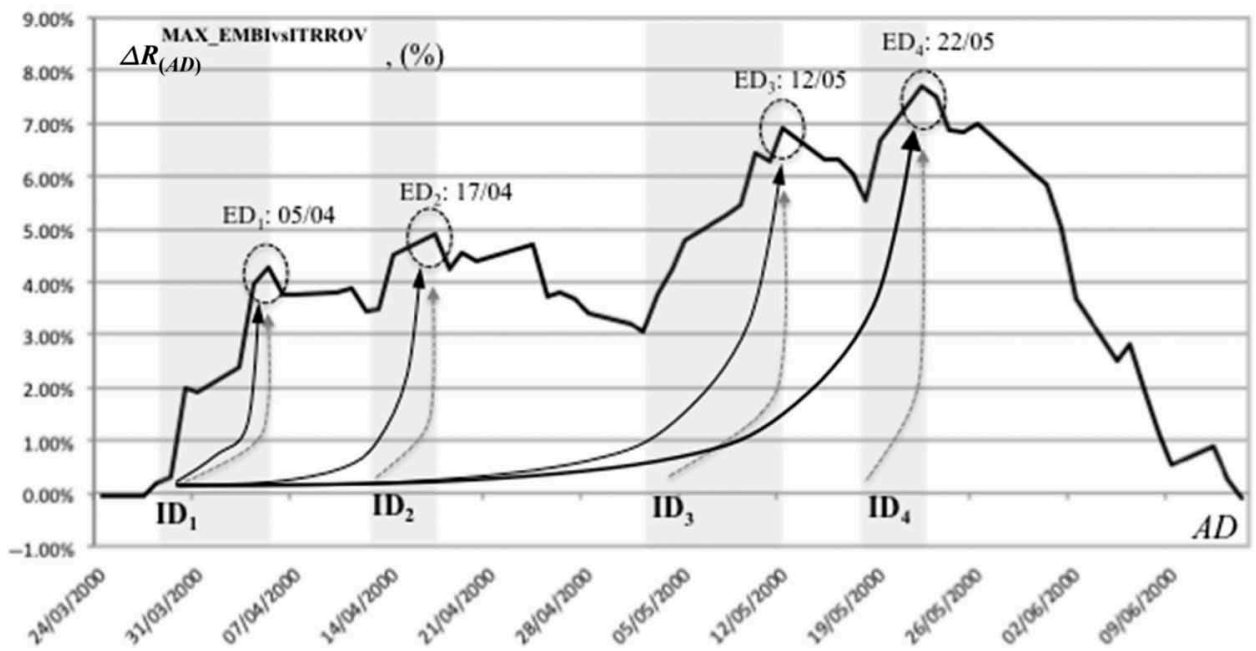

Figure 3. Decomposition of an aggregated flight-to-quality (27 March 2000-22 May 2000). Source: Bloomberg, DataStream and authors' calculations.

Note: The aggregated flight to quality is composed of a series of four weaker flights-to-quality, indicated by the dashed arrows. 


\section{Results}

Our proposed methodology, applied to the ITTROV index and the EMBI index data series, results in an identification of the initial and end dates of 133 flight-to-quality events with the difference in the ITRROV and EMBI total returns over $1 \%, 74$ events with the difference in the ITRROV and EMBI total returns over $2 \%$ and 50 events with the difference in the ITRROV and $E M B I$ total returns higher than $3 \%$.
It is worth mentioning that our methodology, being applied to the historical data series, allows for identification of the flight-to-quality windows by automated determination of the initial (ID) and end $(E D)$ dates of the events based on the computational transformation contained in the extracted data regarding return dynamics of the above-mentioned indexes.

Our results are presented on an annual basis in Table 4, where shadow indicates the initial (ID) and

Table 4. Identified flight-to-quality events and their impacts.

\begin{tabular}{|c|c|c|c|c|c|c|c|c|}
\hline \multirow[b]{2}{*}{$N$} & \multirow[b]{2}{*}{$I D$} & \multirow[b]{2}{*}{$E D$} & \multirow[b]{2}{*}{ ITRROV (\%) } & \multirow[b]{2}{*}{$E M B I(\%)$} & \multicolumn{4}{|c|}{ Event impact parameter (\%) } \\
\hline & & & & & Aggregated & Over $3 \%$ & Over $2 \%$ & Over $1 \%$ \\
\hline 1 & 23 March 1998 & 3 April 1998 & 0.75 & -2.04 & - & - & 2.79 & 2.79 \\
\hline 2 & 14 April 1998 & 27 April 1998 & -0.66 & -1.80 & - & - & - & 1.14 \\
\hline 3 & 1 May 1998 & 18 May 1998 & 0.29 & -3.48 & $\wedge$ & 3.77 & 3.77 & 3.77 \\
\hline 4 & 21 May 1998 & 27 May 1998 & 0.59 & -1.75 & $\wedge$ & - & 2.34 & 2.34 \\
\hline 5 & 5 June 1998 & 15 June 1998 & 1.14 & -3.14 & $\wedge$ & 4.28 & 4.28 & 4.28 \\
\hline 6 & 17 June 1998 & 26 June 1998 & 0.64 & -3.91 & $\wedge$ & 4.55 & 4.55 & 4.55 \\
\hline 7 & 1 July 1998 & 6 July 1998 & 0.33 & -1.61 & 9.40 & - & - & 1.94 \\
\hline 8 & 20 July 1998 & 27 July 1998 & 0.15 & -3.40 & $\wedge$ & 3.55 & 3.55 & 3.55 \\
\hline 9 & 31 July 1998 & 12 August 1998 & 0.85 & -10.89 & $\wedge$ & 11.74 & 11.74 & 11.74 \\
\hline 10 & 14 August 1998 & 27 August 1998 & 1.33 & -22.92 & $\wedge$ & 24.25 & 24.25 & 24.25 \\
\hline 11 & 2 September 1998 & 10 September 1998 & 1.62 & -8.24 & 36.45 & 9.86 & 9.86 & 9.86 \\
\hline 12 & 28 September 1998 & 5 October 1998 & 2.42 & -4.20 & - & 6.62 & 6.62 & 6.62 \\
\hline 13 & 22 October 1998 & 29 October 1998 & 0.74 & -2.70 & - & 3.44 & 3.44 & 3.44 \\
\hline 14 & 6 November 1998 & 12 November 1998 & 0.94 & -2.38 & - & 3.32 & 3.32 & 3.32 \\
\hline 15 & 23 November 1998 & 14 December 1998 & 1.51 & -6.37 & - & 7.88 & 7.88 & 7.88 \\
\hline 16 & 6 January 1999 & 14 January 1999 & 0.42 & -12.18 & - & 12.60 & 12.60 & 12.60 \\
\hline 17 & 20 January 1999 & 25 January 1999 & 0.56 & -4.48 & - & 5.04 & 5.04 & 5.04 \\
\hline 18 & 4 February 1999 & 8 February 1999 & -0.08 & -1.58 & - & - & - & 1.50 \\
\hline 19 & 16 February 1999 & 3 March 1999 & -1.26 & -3.97 & - & - & 2.71 & 2.71 \\
\hline 20 & 7 May 1999 & 24 May 1999 & 0.22 & -7.46 & - & 7.68 & 7.68 & 7.68 \\
\hline 21 & 22 June 1999 & 28 June 1999 & 0.00 & -1.75 & $\wedge$ & - & - & 1.75 \\
\hline 22 & 6 July 1999 & 12 July 1999 & 0.79 & -2.67 & 4.00 & 3.46 & 3.46 & 3.46 \\
\hline 23 & 30 July 1999 & 5 August 1999 & 0.27 & -2.05 & - & - & 2.32 & 2.32 \\
\hline 24 & 17 August 1999 & 20 August 1999 & 0.09 & -1.18 & - & - & - & 1.27 \\
\hline 25 & 10 September 1999 & 24 September 1999 & 0.89 & -0.38 & - & - & - & 1.27 \\
\hline 26 & 8 October 1999 & 15 October 1999 & -0.13 & -1.39 & - & - & - & 1.26 \\
\hline 27 & 26 November 1999 & 1 December 1999 & -0.30 & -1.35 & - & - & - & 1.05 \\
\hline 28 & 3 January 2000 & 12 January 2000 & -0.18 & -1.63 & $\wedge$ & - & - & 1.45 \\
\hline 29 & 24 January 2000 & 31 January 2000 & 0.36 & -1.34 & 2.47 & - & - & 1.70 \\
\hline 30 & 15 February 2000 & 22 February 2000 & 1.02 & -0.40 & - & - & - & 1.42 \\
\hline 31 & 10 March 2000 & 15 March 2000 & 0.65 & -0.70 & - & - & - & 1.35 \\
\hline 32 & 27 March 2000 & 5 April 2000 & 1.57 & -2.70 & $\wedge$ & 4.27 & 4.27 & 4.27 \\
\hline 33 & 12 April 2000 & 17 April 2000 & -0.12 & -1.60 & $\wedge$ & - & - & 1.48 \\
\hline 34 & 2 May 2000 & 12 May 2000 & -0.91 & -4.88 & $\wedge$ & 3.97 & 3.97 & 3.97 \\
\hline 35 & 18 May 2000 & 22 May 2000 & 0.62 & -1.66 & 7.71 & - & 2.28 & 2.28 \\
\hline 36 & 11 August 2000 & 21 August 2000 & 0.19 & -0.99 & - & - & - & 1.18 \\
\hline 37 & 6 September 2000 & 18 September 2000 & -0.55 & -3.27 & $\wedge$ & - & 2.72 & 2.72 \\
\hline 38 & 4 October 2000 & 26 October 2000 & 1.55 & -4.31 & 6.82 & 5.86 & 5.86 & 5.86 \\
\hline 39 & 2 November 2000 & 8 November 2000 & -0.42 & -2.79 & - & - & 2.37 & 2.37 \\
\hline 40 & 21 November 2000 & 30 November 2000 & 1.18 & -1.17 & - & - & 2.35 & 2.35 \\
\hline 41 & 29 January 2001 & 7 February 2001 & 0.91 & -0.24 & - & - & - & 1.15 \\
\hline 42 & 15 February 2001 & 28 February 2001 & 1.62 & -1.56 & $\wedge$ & 3.18 & 3.18 & 3.18 \\
\hline 43 & 9 March 2001 & 23 March 2001 & 0.87 & -4.33 & $\wedge$ & 5.20 & 5.20 & 5.20 \\
\hline 44 & 28 March 2001 & 3 April 2001 & 0.33 & -1.02 & $\wedge$ & - & - & 1.35 \\
\hline 45 & 10 April 2001 & 23 April 2001 & -0.20 & -5.79 & 7.60 & 5.59 & 5.59 & 5.59 \\
\hline 46 & 24 May 2001 & 1 June 2001 & 0.86 & -0.74 & - & - & - & 1.60 \\
\hline
\end{tabular}


Table 4. (Continued).

\begin{tabular}{|c|c|c|c|c|c|c|c|c|}
\hline \multirow[b]{2}{*}{ N } & \multirow[b]{2}{*}{ ID } & \multirow[b]{2}{*}{$E D$} & \multirow[b]{2}{*}{ ITRROV (\%) } & \multirow[b]{2}{*}{$E M B I(\%)$} & \multicolumn{4}{|c|}{ Event impact parameter (\%) } \\
\hline & & & & & Aggregated & Over $3 \%$ & Over $2 \%$ & Over $1 \%$ \\
\hline $\begin{array}{l}47 \\
48\end{array}$ & $\begin{array}{r}8 \text { June } 2001 \\
26 \text { June } 2001\end{array}$ & $\begin{array}{l}18 \text { June } 2001 \\
12 \text { July } 2001\end{array}$ & $\begin{array}{l}0.76 \\
0.09\end{array}$ & $\begin{array}{l}-1.85 \\
-9.78\end{array}$ & $\hat{\wedge}$ & $-\overline{9}$ & $\begin{array}{l}2.61 \\
9.87\end{array}$ & $\begin{array}{l}2.61 \\
9.87\end{array}$ \\
\hline $\begin{array}{l}49 \\
50 \\
51\end{array}$ & $\begin{array}{l}23 \text { July } 2001 \\
9 \text { August } 2001 \\
16 \text { August } 2001\end{array}$ & $\begin{array}{l}1 \text { August } 2001 \\
14 \text { August } 2001 \\
21 \text { August } 2001\end{array}$ & $\begin{array}{l}0.42 \\
0.30 \\
0.29\end{array}$ & $\begin{array}{l}-3.23 \\
-0.71 \\
-3.11\end{array}$ & $\begin{array}{l}- \\
- \\
-\end{array}$ & $\begin{array}{l}3.65 \\
- \\
3.40\end{array}$ & $\begin{array}{l}3.65 \\
- \\
3.40\end{array}$ & $\begin{array}{l}3.65 \\
1.01 \\
3.40\end{array}$ \\
\hline $\begin{array}{l}52 \\
53 \\
54\end{array}$ & $\begin{array}{l}4 \text { September } 2001 \\
19 \text { September } 2001 \\
22 \text { October } 2001\end{array}$ & $\begin{array}{l}14 \text { September } 2001 \\
5 \text { October } 2001 \\
2 \text { November } 2001\end{array}$ & $\begin{array}{l}2.37 \\
1.41 \\
1.68\end{array}$ & $\begin{array}{l}-3.92 \\
-3.35 \\
-4.53\end{array}$ & $\hat{\wedge}$ & $\begin{array}{l}6.29 \\
4.76 \\
6.21\end{array}$ & $\begin{array}{l}6.29 \\
4.76 \\
6.21\end{array}$ & $\begin{array}{l}6.29 \\
4.76 \\
6.21\end{array}$ \\
\hline $\begin{array}{l}55 \\
56 \\
57 \\
58 \\
59 \\
60\end{array}$ & $\begin{array}{l}15 \text { November } 2001 \\
26 \text { November } 2001 \\
14 \text { December } 2001 \\
4 \text { January } 2002 \\
24 \text { January } 2002 \\
12 \text { April } 2002\end{array}$ & $\begin{array}{l}19 \text { November } 2001 \\
30 \text { November } 2001 \\
24 \text { December } 2001 \\
15 \text { January } 2002 \\
4 \text { February } 2002 \\
10 \text { May } 2002\end{array}$ & $\begin{array}{l}0.03 \\
1.15 \\
0.44 \\
1.96 \\
0.95 \\
0.89\end{array}$ & $\begin{array}{l}-1.25 \\
-2.26 \\
-1.01 \\
-0.32 \\
-0.71 \\
-2.16\end{array}$ & $\begin{array}{l}- \\
- \\
- \\
- \\
-\end{array}$ & $\begin{array}{l}- \\
3.41 \\
- \\
- \\
- \\
3.05\end{array}$ & $\begin{array}{l}- \\
3.41 \\
- \\
2.28 \\
- \\
3.05\end{array}$ & $\begin{array}{l}1.28 \\
3.41 \\
1.45 \\
2.28 \\
1.66 \\
3.05\end{array}$ \\
\hline $\begin{array}{l}61 \\
62 \\
63 \\
64 \\
65 \\
66 \\
67 \\
68 \\
69 \\
70 \\
71\end{array}$ & $\begin{array}{l}16 \text { May } 2002 \\
10 \text { June } 2002 \\
28 \text { June } 2002 \\
8 \text { August } 2002 \\
30 \text { August } 2002 \\
25 \text { September } 2002 \\
4 \text { October } 2002 \\
2 \text { December } 2002 \\
23 \text { December } 2002 \\
13 \text { January } 2003 \\
13 \text { May } 2003\end{array}$ & $\begin{array}{l}6 \text { June } 2002 \\
21 \text { June } 2002 \\
30 \text { July } 2002 \\
13 \text { August } 2002 \\
23 \text { September } 2002 \\
30 \text { September } 2002 \\
9 \text { October } 2002 \\
5 \text { December } 2002 \\
30 \text { December } 2002 \\
24 \text { January } 2003 \\
20 \text { May } 2003\end{array}$ & $\begin{array}{l}1.14 \\
1.51 \\
1.68 \\
1.31 \\
2.25 \\
0.81 \\
0.54 \\
0.57 \\
1.06 \\
1.25 \\
1.41\end{array}$ & $\begin{array}{r}-2.80 \\
-4.89 \\
-5.34 \\
-2.80 \\
-2.31 \\
-1.06 \\
-1.34 \\
-0.86 \\
0.04 \\
-1.26 \\
-1.61\end{array}$ & $\begin{array}{c}\wedge \\
10.55 \\
- \\
- \\
- \\
- \\
- \\
- \\
- \\
- \\
-\end{array}$ & $\begin{array}{l}3.94 \\
6.40 \\
7.02 \\
4.11 \\
4.56 \\
- \\
- \\
- \\
- \\
- \\
3.02\end{array}$ & $\begin{array}{l}3.94 \\
6.40 \\
7.02 \\
4.11 \\
4.56 \\
- \\
- \\
- \\
- \\
2.51 \\
3.02\end{array}$ & $\begin{array}{l}3.94 \\
6.40 \\
7.02 \\
4.11 \\
4.56 \\
1.87 \\
1.88 \\
1.43 \\
1.02 \\
2.51 \\
3.02 \\
\end{array}$ \\
\hline $\begin{array}{l}72 \\
73\end{array}$ & $\begin{array}{l}17 \text { June } 2003 \\
25 \text { June } 2003\end{array}$ & $\begin{array}{l}23 \text { June } 2003 \\
7 \text { July } 2003\end{array}$ & $\begin{array}{l}-0.22 \\
-1.38\end{array}$ & $\begin{array}{l}-2.21 \\
-3.07\end{array}$ & $\hat{\wedge}$ & $\begin{array}{l}- \\
-\end{array}$ & $\begin{array}{l}- \\
-\end{array}$ & $\begin{array}{l}1.99 \\
1.69\end{array}$ \\
\hline $\begin{array}{l}74 \\
75 \\
76 \\
77 \\
78\end{array}$ & $\begin{array}{l}21 \text { July } 2003 \\
19 \text { September } 2003 \\
16 \text { October } 2003 \\
8 \text { January } 2004 \\
12 \text { February } 2004\end{array}$ & $\begin{array}{l}6 \text { August } 2003 \\
30 \text { September } 2003 \\
28 \text { October } 2003 \\
6 \text { February } 2004 \\
19 \text { February } 2004\end{array}$ & $\begin{array}{r}-0.74 \\
1.33 \\
1.51 \\
1.05 \\
0.24\end{array}$ & $\begin{array}{r}-3.73 \\
0.17 \\
-0.71 \\
-1.96 \\
-0.87\end{array}$ & $\begin{array}{l}- \\
- \\
- \\
-\end{array}$ & $\begin{array}{l}- \\
- \\
- \\
3.01 \\
-\end{array}$ & $\begin{array}{l}2.99 \\
- \\
2.22 \\
3.01 \\
-\end{array}$ & $\begin{array}{l}2.99 \\
1.16 \\
2.22 \\
3.01 \\
1.11\end{array}$ \\
\hline $\begin{array}{l}79 \\
80\end{array}$ & $\begin{array}{l}13 \text { April } 2004 \\
23 \text { April } 2004\end{array}$ & $\begin{array}{l}21 \text { April } 2004 \\
10 \text { May } 2004\end{array}$ & $\begin{array}{l}-0.53 \\
-1.37\end{array}$ & $\begin{array}{l}-2.35 \\
-7.92\end{array}$ & $\hat{7}$ & - & - & $\begin{array}{l}1.82 \\
6.55\end{array}$ \\
\hline $\begin{array}{l}81 \\
82 \\
83 \\
84 \\
85 \\
86\end{array}$ & $\begin{array}{l}7 \text { June } 2004 \\
\text { 12- October } 2004 \\
29 \text { December } 2004 \\
8 \text { March } 2005 \\
3 \text { October } 2005 \\
\text { 27 February } 2006\end{array}$ & $\begin{array}{l}14 \text { June } 2004 \\
25 \text { October } 2004 \\
18 \text { January } 2005 \\
15 \text { April } 2005 \\
14 \text { October } 2005 \\
10 \text { April } 2006\end{array}$ & $\begin{array}{r}-0.57 \\
0.75 \\
0.81 \\
0.87 \\
-0.34 \\
-1.14\end{array}$ & $\begin{array}{l}-1.72 \\
-0.78 \\
-0.57 \\
-3.23 \\
-2.85 \\
-2.94\end{array}$ & $\begin{array}{l}- \\
- \\
- \\
- \\
- \\
-\end{array}$ & $\begin{array}{l}- \\
- \\
- \\
4.10 \\
- \\
-\end{array}$ & $\begin{array}{l}- \\
- \\
- \\
4.10 \\
2.51 \\
-\end{array}$ & $\begin{array}{l}1.15 \\
1.53 \\
1.38 \\
4.10 \\
2.51 \\
1.80\end{array}$ \\
\hline $\begin{array}{l}87 \\
88 \\
89\end{array}$ & $\begin{array}{l}3 \text { May2006 } \\
1 \text { June } 2006 \\
16 \text { June } 2006\end{array}$ & $\begin{array}{l}24 \text { May } 2006 \\
13 \text { June } 2006 \\
27 \text { June } 2006\end{array}$ & $\begin{array}{r}0.73 \\
0.85 \\
-0.24\end{array}$ & $\begin{array}{l}-2.22 \\
-0.20 \\
-1.71\end{array}$ & $\begin{array}{c}\hat{\wedge} \\
3.65\end{array}$ & $\begin{array}{l}- \\
- \\
-\end{array}$ & $\begin{array}{l}2.95 \\
- \\
-\end{array}$ & $\begin{array}{l}2.95 \\
1.05 \\
1.47\end{array}$ \\
\hline $\begin{array}{l}90 \\
91\end{array}$ & $\begin{array}{l}5 \text { September } 2006 \\
22 \text { February } 2007\end{array}$ & $\begin{array}{l}22 \text { September } 2006 \\
5 \text { March } 2007\end{array}$ & $\begin{array}{l}1.11 \\
1.21\end{array}$ & $\begin{array}{l}-0.24 \\
-0.18\end{array}$ & - & - & - & $\begin{array}{l}1.35 \\
1.39\end{array}$ \\
\hline $\begin{array}{l}92 \\
93 \\
94\end{array}$ & $\begin{array}{c}23 \text { May } 2007 \\
18 \text { June } 2007 \\
6 \text { July } 2007\end{array}$ & $\begin{array}{l}13 \text { June } 2007 \\
29 \text { June } 2007 \\
26 \text { July } 2007\end{array}$ & $\begin{array}{r}-1.17 \\
0.77 \\
2.25\end{array}$ & $\begin{array}{l}-2.70 \\
-0.49 \\
-1.57 \%\end{array}$ & $\hat{\wedge}$ & $\begin{array}{l}- \\
- \\
3.82\end{array}$ & $\begin{array}{l}- \\
- \\
3.82\end{array}$ & $\begin{array}{l}1.53 \\
1.26 \\
3.82\end{array}$ \\
\hline $\begin{array}{l}95 \\
96 \\
97\end{array}$ & $\begin{array}{l}8 \text { August } 2007 \\
4 \text { September } 2007 \\
15 \text { October } 2007\end{array}$ & $\begin{array}{l}16 \text { August } 2007 \\
10 \text { September } 2007 \\
24 \text { October } 2007\end{array}$ & $\begin{array}{l}1.47 \\
1.31 \\
1.87\end{array}$ & $\begin{array}{r}-2.26 \\
0.23 \\
0.59\end{array}$ & $\begin{array}{l}- \\
- \\
-\end{array}$ & $\begin{array}{l}3.73 \\
- \\
-\end{array}$ & $\begin{array}{l}3.73 \\
- \\
-\end{array}$ & $\begin{array}{l}3.73 \\
1.08 \\
1.28\end{array}$ \\
\hline $\begin{array}{l}98 \\
99\end{array}$ & $\begin{array}{l}31 \text { October } 2007 \\
14 \text { November } 2007\end{array}$ & $\begin{array}{l}12 \text { November } 2007 \\
26 \text { November } 2007\end{array}$ & $\begin{array}{l}1.50 \\
2.29\end{array}$ & $\begin{array}{l}-0.75 \\
-0.78\end{array}$ & $\hat{4.97}$ & $\begin{array}{l}- \\
3.07\end{array}$ & $\begin{array}{l}2.25 \\
3.07\end{array}$ & $\begin{array}{l}2.25 \\
3.07\end{array}$ \\
\hline 100 & 14 December 2007 & 20 December 2007 & 1.20 & 0.18 & & & & 1.02 \\
\hline $\begin{array}{l}101 \\
102 \\
103 \\
104\end{array}$ & $\begin{array}{l}26 \text { December } 2007 \\
10 \text { January } 2008 \\
30 \text { January } 2008 \\
26 \text { February } 2008\end{array}$ & $\begin{array}{c}4 \text { January } 2008 \\
23 \text { January } 2008 \\
11 \text { February } 2008 \\
3 \text { March } 2008\end{array}$ & $\begin{array}{l}2.35 \\
2.48 \\
0.90 \\
1.72\end{array}$ & $\begin{array}{r}0.48 \\
0.02 \\
-0.88 \\
0.19\end{array}$ & $\begin{array}{c}\hat{\wedge} \\
\hat{4} \\
4.33\end{array}$ & $\begin{array}{l}- \\
- \\
- \\
-\end{array}$ & $\begin{array}{l}- \\
2.46 \\
- \\
-\end{array}$ & $\begin{array}{l}1.87 \\
2.46 \\
1.78 \\
1.53\end{array}$ \\
\hline $\begin{array}{l}105 \\
106 \\
107\end{array}$ & $\begin{array}{l}5 \text { March } 2008 \\
13 \text { June } 2008 \\
23 \text { July } 2008\end{array}$ & $\begin{array}{l}17 \text { March } 2008 \\
15 \text { July } 2008 \\
18 \text { August } 2008\end{array}$ & $\begin{array}{l}2.04 \\
2.73 \\
2.15\end{array}$ & $\begin{array}{r}-0.70 \\
-1.21 \\
0.85\end{array}$ & $\begin{array}{l}- \\
- \\
-\end{array}$ & $\begin{array}{l}- \\
3.94 \\
-\end{array}$ & $\begin{array}{c}2.74 \\
3.94 \\
-\end{array}$ & $\begin{array}{l}2.74 \\
3.94 \\
1.30\end{array}$ \\
\hline $\begin{array}{l}108 \\
109\end{array}$ & $\begin{array}{l}29 \text { August } 2008 \\
22 \text { September } 2008\end{array}$ & $\begin{array}{l}17 \text { September } 2008 \\
10 \text { October } 2008\end{array}$ & $\begin{array}{l}2.53 \\
0.77\end{array}$ & $\begin{array}{r}-5.71 \\
-16.22\end{array}$ & $\hat{\wedge}$ & $\begin{array}{r}8.24 \\
16.99\end{array}$ & $\begin{array}{r}8.24 \\
16.99\end{array}$ & $\begin{array}{r}8.24 \\
16.99\end{array}$ \\
\hline
\end{tabular}


Table 4. (Continued).

\begin{tabular}{|c|c|c|c|c|c|c|c|c|}
\hline \multirow[b]{2}{*}{ N } & \multirow[b]{2}{*}{$I D$} & \multirow[b]{2}{*}{$E D$} & \multirow[b]{2}{*}{ ITRROV (\%) } & \multirow[b]{2}{*}{$E M B I(\%)$} & \multicolumn{4}{|c|}{ Event impact parameter (\%) } \\
\hline & & & & & Aggregated & Over $3 \%$ & Over $2 \%$ & Over $1 \%$ \\
\hline 110 & 14 October 2008 & 24 October 2008 & 1.43 & -15.82 & 30.53 & 17.25 & 17.25 & 17.25 \\
\hline 111 & 4 November 2008 & 20 November 2008 & 3.49 & -6.23 & - & 9.72 & 9.72 & 9.72 \\
\hline 112 & 6 January 2009 & 15 January 2009 & 1.41 & -1.32 & - & - & 2.73 & 2.73 \\
\hline 113 & 9 February 2009 & 17 February 2009 & 1.59 & -1.94 & - & 3.53 & 3.53 & 3.53 \\
\hline 114 & 26 February 2009 & 6 March 2009 & 0.90 & -1.39 & - & - & 2.29 & 2.29 \\
\hline 115 & 8 May 2009 & 13 May 2009 & 1.03 & -0.80 & - & - & - & 1.83 \\
\hline 116 & 12 June 2009 & 23 June 2009 & 1.27 & -1.61 & $\wedge$ & - & 2.88 & 2.88 \\
\hline 117 & 1 July 2009 & 8 July 2009 & 1.27 & -0.38 & 2.96 & - & - & 1.65 \\
\hline 118 & 7 August 2009 & 17 August 2009 & 1.75 & -0.45 & $\wedge$ & - & 2.20 & 2.20 \\
\hline 119 & 21 August 2009 & 2 September 2009 & 1.50 & 0.26 & 2.38 & - & - & 1.24 \\
\hline 120 & 16 September 2009 & 28 September 2009 & 0.91 & -0.26 & - & - & - & 1.17 \\
\hline 121 & 14 October 2009 & 28 October 2009 & 0.20 & -2.45 & - & - & 2.65 & 2.65 \\
\hline 122 & 18 November 2009 & 30 November 2009 & 0.98 & -0.49 & - & - & - & 1.47 \\
\hline 123 & 11 January 2010 & 5 February 2010 & 1.65 & -1.57 & - & 3.22 & 3.22 & 3.22 \\
\hline 124 & 15 April 2010 & 7 May 2010 & 2.12 & -3.35 & $\wedge$ & 5.47 & 5.47 & 5.47 \\
\hline 125 & 13 May 2010 & 25 May 2010 & 1.66 & -2.57 & 6.78 & 4.23 & 4.23 & 4.23 \\
\hline 126 & 3 June 2010 & 8 June 2010 & 0.99 & -0.90 & - & - & - & 1.89 \\
\hline 127 & 21 June 2010 & 29 June 2010 & 1.32 & -0.12 & - & - & - & 1.44 \\
\hline 128 & 9 August 2010 & 16 August 2010 & 1.20 & 0.11 & - & - & - & 1.09 \\
\hline 129 & 23 August 2010 & 31 August 2010 & 0.61 & -1.25 & - & - & - & 1.86 \\
\hline 130 & 14 October 2010 & 19 October 2010 & 0.20 & -0.84 & - & - & - & 1.04 \\
\hline 131 & 5 November 2010 & 16 November 2010 & -1.26 & -3.26 & $\wedge$ & - & 2.00 & 2.00 \\
\hline 132 & 19 November 2010 & 30 November 2010 & 0.43 & -1.46 & 3.25 & - & - & 1.89 \\
\hline 133 & 14 December 2010 & 17 December 2010 & 0.53 & -1.13 & - & - & - & 1.66 \\
\hline
\end{tabular}

final $(E D)$ dates of the aggregated flights-to-quality, as well as their aggregate strengths and the sets of minor events identified within the aggregated time intervals.

Table 4 contains the initial (ID) and end dates $(E D)$ of the flight-to-quality occurrences, the performance of ITRROV and EMBI, as well as the differential total return between the ITRROV and EMBI indexes from the beginning to the end of the subjacent phenomenon compared to the EIP limit conditions in order to demonstrate that the selection of flight-to-quality is dependent on the minimal strength of the events to be selected for specific analyses.

\section{Statistical analysis of flights-to-quality over 1998-2010}

Additionally, a statistical analysis is performed in order to study homogeneity of the observed sample of 133 flights-to-quality. We divide the whole sample into two subsamples using a clustering approach based on SD minimization. That is, we arrange the strength of the events in descending order and vary a number of occurrences in the subsamples from 1 to 133 . For each of 133 divisions of the whole array, the SD is calculated in such a way that, instead of the whole sample average, the respective averages of sub-arrays are used to calculate the deviation of each flight-toquality strength according to its positioning in one of the sub-arrays. Figure 4 shows the $\mathrm{SD}$ as a function of the number of the occurrences in the first sub-array with more impactful events, i.e. events exhibiting events' strengths superior to the occurrences in the other array.

The sub-arrays of the 11 most impactful events and the 122 weaker occurrences diminish the SD of the whole sample of $3.36 \%$, to the $2.04 \%$ value of the SD parameter, which represents a drop circa $40 \%$ of the initial value. Thus, the threshold of the 11 most impactful events divides the whole sample into two sub-arrays the most homogeneous over their respective population of the flights-to-quality, while one sub-array, from a statistical point of view, is significantly different from another.

The statistically selected sub-array of the most impactful events contains the following 11 flightto-quality occurrences: 31 July 1998-12 August 1998 (Russian crisis); 14 August 1998-27 August 1998 (Russian crisis); 2 September 1998-10 September 1998 (Russian crisis); 23 November 1998-14 December 1998 (Russian crisis); 6 January 1999-14 January 1999 (Brazilian exchange rate crisis); 7 May 1999-24 May 1999 (Kosovo crisis); 


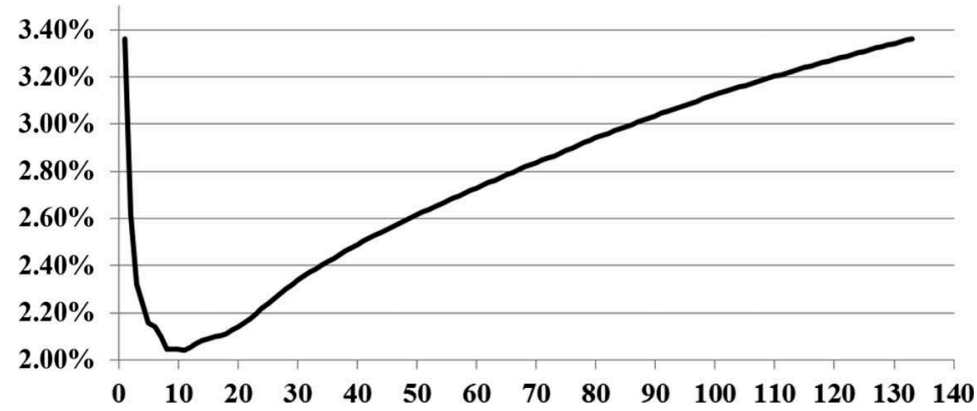

Figure 4. SD as a function of the number of the flights-to-quality in the sub-array of the most impactful occurrences. Source: Bloomberg, DataStream and authors' calculations.

Notes: The event impact parameter (EIP) which desiccates the whole sample into the two most homogeneous sub-arrays lays within the EIP interval between $7.02 \%$ and $7.68 \%$, figures which correspond to the eleventh and twelfth most impactful occurrences, respectively. Thus, minimum of the curve on the graphic corresponds to the 11 most impactful occurrences in the first sub-array and 122 occurrences in the sub-array of weaker events.

26 June 2001-12 July 2001 (Latin America coffee crisis); 29 August 2008-17 September 2008 (preLehman phase of global financial crisis); 22 September 2008-10 October 2008 (post-Lehman phase of global financial crisis); 14 October 200824 October 2008 (post-Lehman phase of global financial crisis); and 4 November 2008-20 November 2008 (post-Lehman phase of global financial crisis). In fact, these are events which correspond to major crisis situations that resulted in significant turmoil in the debt markets of emerging countries.

Still, such statistical approach risks 'throwing baby out with the bathwater' for there could be flight-toquality occurrences, which, although not exhibiting major strength, are important from the point of view of comprehension of these phenomena. Thus, more precise economic analysis based on the presented earlier typology of events is needed.

\section{Economic interpretation of flights-to-quality over 1998-2010}

All 133 flights-to-quality, identified by applying our proposed automated technique to the historical data series of the EMBI and ITRROV indexes, are classified in accordance with the proposed typology. To perform this typological classification of the identified occurrences, the total return of risky (EMBI index) and safe (ITRROV index) assets are analysed separately within the respective flight-to-quality window, and the types are ascribed to the events according to Table 2. In total, 100 events out of 133 are ascribed to the subtype 1A Downturn flight-to-quality; 11 episodes are of subtype 1B Start-of-thedownturn flight-to-quality; and 22 cases belong to the type 2 Upturn flight-to-quality.

The relationship between the occurrences of the subtype $1 \mathrm{~A}$, subtype $1 \mathrm{~B}$ and type 2 of flight-to-quality and economic growth rates is graphically analysed. The US and world annual GDP growth rates, according to the World Bank data (http://databank. worldbank.org/data), are considered for this study. To graphically depict the position of the identified specific flight-to-quality events on the time scale (see Fig. 5), the data were specified in the following manner. First, for each event, the respective initial date (ID) was selected and stored. Then, the vertical line corresponding to the $I D$ abscissa was drawn. Thus, for each flight-to-quality, the vertical line, corresponding to the ignition of the event, was plotted.

The higher frequency of the vertical lines corresponding to subtype 1A Downturn flight-to-quality events coincides with the decreasing slope of GDP growth rates, measured by the right-hand scale of Fig. 5. As could be observed in Fig. 5, these Downturn flight-to-quality predominantly happens over the periods of economic slowdown and contraction. Within the analysed period, those phases could be associated with 1998 (Russian bond default and other emerging market distresses), the first half of 2000 (dot-com crash), 2001-2002 (September 11 attack and war on terror, Brazil presidential election uncertainty) and the second quarter of 2007-2010 (US subprime mortgage crisis ignition resulting in 


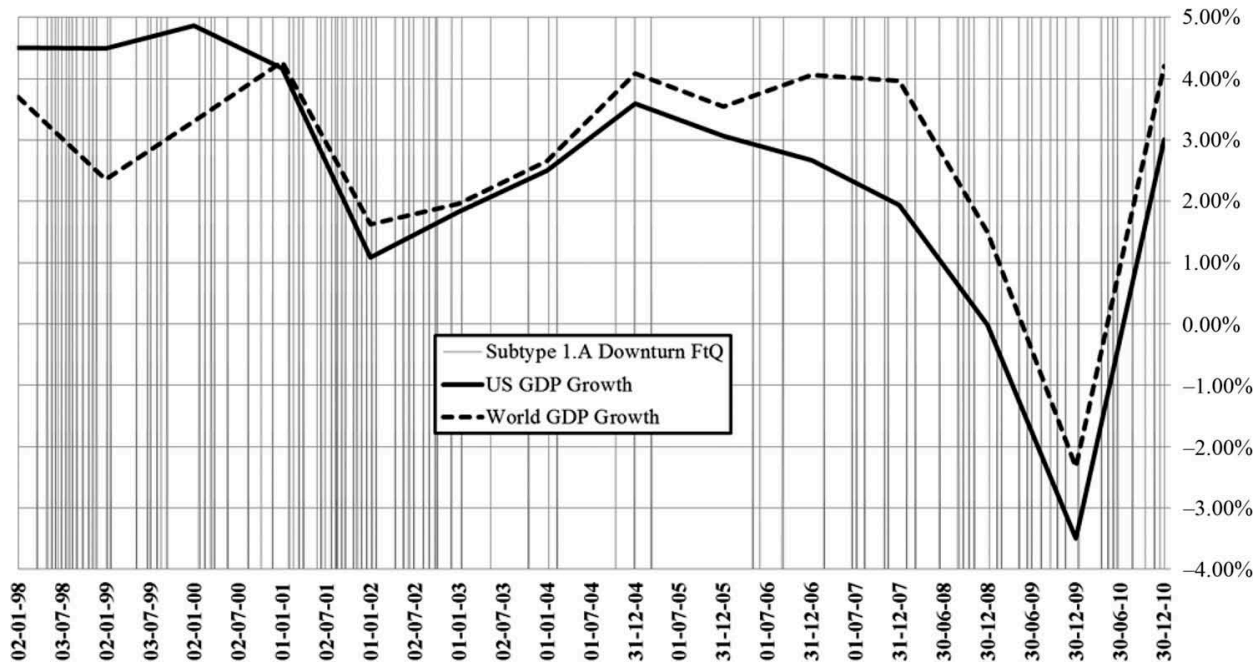

Figure 5. Occurrences of the subtype 1A Downturn flights-to-quality, along with the US and the world annual GDP growth rates over 1998-2010. Source: World Bank, Bloomberg, DataStream and authors' calculations.

the global financial crisis). In graphical terms, these periods could be recognized by higher density of individual events making separate event lines resemble shadowed frames.

As expected, the higher frequency of the subtype 1A of flight-to-quality coincides with the decreasing slope of the GDP growth rate curves, especially so in case of the world GDP (see year 1998).

The subtype 1B Start-of-the-downturn flights-toquality is observed prior to the turning points of GDP rate dynamics (see Fig. 6). Their major concentration coincides with the turning point when the accentuated slowdown of the GDP growth rate curves begins, especially so in case of the world GDP (2007-2008). Thus, subtype 1B events could eventually alarm of upcoming changes from an economic growth to a slowdown and vice versa. It is worth noting that diagnostics and analyses of the flight-to-quality, obeying characteristics of subtype $1 \mathrm{~B}$, are addressed for the first time.

Our results suggest that flights-to-quality of subtype $1 \mathrm{~B}$ happen around the turning points, which are characterized by the initial doubts of the market participants regarding the continuation of the economic expansion. Additionally, these events can be considered as useful hints or the alarm signals warning of further decline in the risk-free interest rates. It is worth noting that in all cases considered in this study they are followed by local minima of the midterm risk-free rate (we analyse the US generic

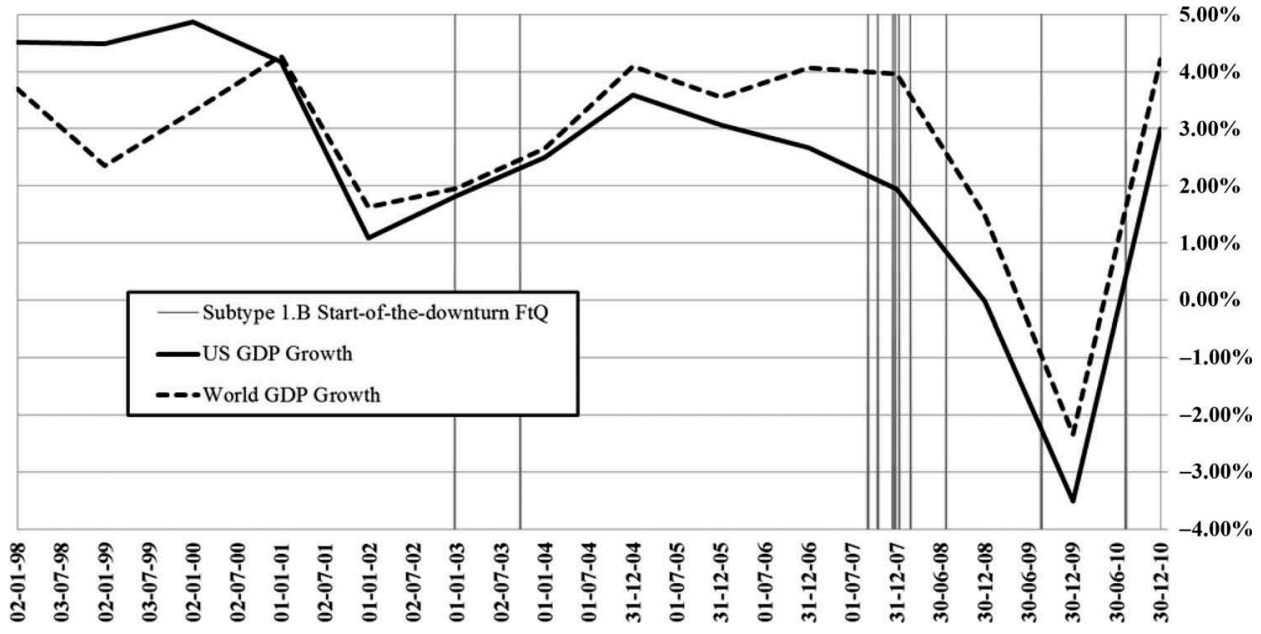

Figure 6. Occurrences of the subtype 1B Start-of-the-downturn flights-to-quality along with the US and the world annual GDP growth rates over 1998-2010. Source: World Bank, Bloomberg, DataStream and authors' calculations. 


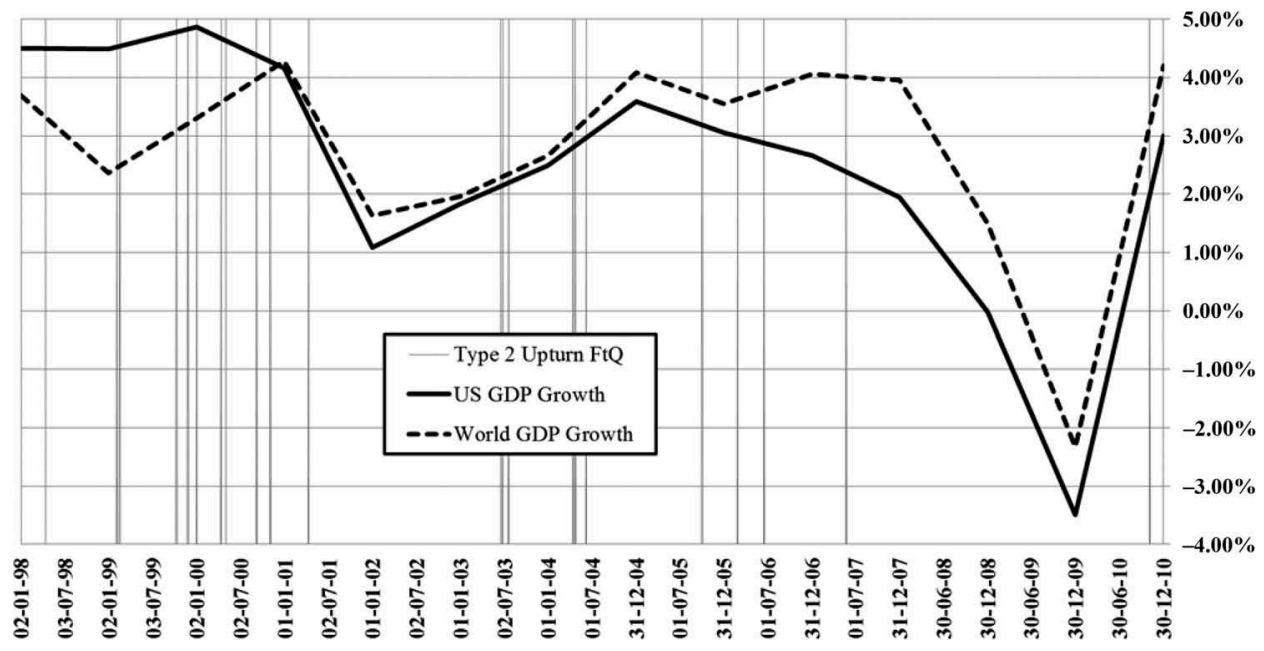

Figure 7. Occurrences of the type 2 Upturn flights-to-quality along with the US and the world annual GDP growth rates over 1998-2010. Source: World Bank, Bloomberg, DataStream and authors' calculations.

government 5-year yield), with their values being inferior to those of the end dates of the flights-toquality of subtype $1 \mathrm{~B}$.

In order to illustrate the given economic interpretation of the subtype 1B of flight-to-quality, Fig. 6 depicts the relationship between the occurrences of these events and the US and the world economic growth rates.

As expected, the major concentration of the subtype $1 \mathrm{~B}$ of flight-to-quality coincides with the turning point when the accentuated slowdown of the GDP growth rate curves begins, especially so in case of the world GDP (see 2007-2008).

The major concentrations of the identified type 2 Upturn flight-to-quality coincide with the increase in GDP growth rate (see Fig. 7). Events of type 2 mostly happen over the periods of an accelerated growth and economic expansion. Generally, within the analysed period, these phases could be associated with 1999 and 2000 (technological boom); 2002-2007 (global economic expansion and emerging markets growth) and the last quarter of 2010 (partial recovery from the global financial crisis).

As expected, the major concentration of type 2 of flight-to-quality coincides with the increasing slope of the GDP growth rate curves, especially so in case of the world GDP.

The least frequently observed type of flight-toquality is the subtype $1 \mathrm{~B}$ Start-of-the-downturn flight-to-quality, which accounts only for 11 out of the total of 133 flight-to-quality occurrences. This case represents just $8 \%$ of the studied sample. On the contrary, the subtype 1A Downturn flight-to-quality is the most common typological class and represents $75 \%$ of the total number of occurrences. In its turn, the type 2 Upturn flight-to-quality accounts for the rest of the $17 \%$ of the totality of the occurrences and, thus, represents a rather rare type of flight-to-quality while compared to the frequency of the subtype $1 \mathrm{~A}$ Downturn flight-to-quality occurrences.

This distribution of the events among the typology classes can be understood through the following logic. Any type of flight-to-quality event is essentially a mini-crisis situation. In its turn, the phenomena of downturn type 1, according to the proposed typological classification, occur within the periods of the decrease in risk-free interest rates. These periods usually coincide with the phases of financial turmoil and economy distress. The latter are revealed through or represent by themselves the proper flight-to-quality events. So, it is expectable that the number of downturn type 1 events must be considerably higher in comparison with upturn type 2 of the flight-to-quality, as it is 111 events belonging to downturn type 1 versus only 22 events of the upturn type 2 . This is because the events of upturn type 2 happen along increasing trends in risk-free interest rates, which usually accompanies periods of economic prosperity, where probability of crisis to happen is low and the flight-to-quality of upturn type 2 can be seen as a temporary and rare re-evaluation of investors' expectations.

In respect to the relatively low frequency of the subtype 1B Start-of-the-downturn flight-to-quality, 
it can be understood through the following considerations. The fact that under subtype $1 \mathrm{~B}$ the risky assets exhibit positive returns means that aversion towards the risky assets does not cause a sufficient widening of the spread to overcome the positive impact on their performance from the decrease in the risk-free interest rates. We ascribe such episodes to the initial worries of the investors regarding the overall state of the economy as they coincide with switches between expansion and slowdown phases and vice versa.

\section{Rethinking economics of the integrated interest rate and credit risk management}

Flight-to-quality events represent occurrences of downside risk. They are especially important in the context of credit risk and interest risk management, by fixed-income portfolio managers and regulators. These two risks are usually analysed separately and not through a holistic approach that considers aggregate changes in bond yields. A theoretical justification of a split of liquidity, credit and interest rate risk derives from Black's (1970) economic thinking:

(...) a long term corporate bond could actually be sold to three separate persons. One would supply the money for the bond; one would bear the interest rate risk, and one would bear the risk of default. The last two would not have to put up any capital for the bond, though they might have to post some sort of collateral.

Thus, he anticipated two derivative instruments: IRS and credit default swaps (CDS).

Many financial institutions sum independent impacts of diverse risks to access their necessity of capital, assuming a perfect positive correlation among the risks. The correlation between credit risk and interest rate changes is addressed by Kiesel, Perraudin, and Taylor (2002). As interest rate and credit risk interaction is complex (Chen, Cheng, and $\mathrm{Wu} 2013$ ), it is justified to move from the independent analyses of risks to a risk integration approach. Jarrow and Turnbull (2000) explicitly model together market risk and credit risk. A similar aggregated modelling of credit and interest rate risk appeared later. Alessandri and Drehmann (2010) model bank economic capital assuming that these risks amplify one another. And our findings show that the interaction of these risks is especially important within the flight-to-quality time windows linked to the business cycle.

The study by Alessandri and Drehmann (2010), for example, arbitrarily assumes that borrowers are more likely to default when interest rates are high. This assumption is not corroborated by our results and by results of other researchers which, depending on the geography, sector, creditworthiness and time horizons, arrive at conclusions that credit risk spreads do not act as interest rates risk enhancers. In general, hypothetically speaking, credit spreads may widen as interest rates rise, but historically they have not. For instance, Bonfim and Soares (2013) do not confirm an increase in the likelihood of default in the aftermath of a period of lower monetary policy rates. This statement is in direct agreement with our findings. Our flight-to-quality studies, under both recession and expansion conditions, evidence that interest rate risk and credit risk mitigate adverse outcomes of each other, rather than amplify negative impacts.

The automated mathematical algorithm proposed in Section III, for identifying exact time windows within which flights-to-quality occur, is a useful tool for defining historical stress test scenarios. The application of our methodology eliminates subjectivity, usually present during the selection of time intervals based purely on graph analysis and/or expert judgement as commonly happens in many banks and financial institutions.

Before proceeding on our discussion, it is important to comment on the applicability of our approach to the universe of financial products. In the present research, we exemplify the performance of our methodology by applying it to fixed income instruments. More precisely, to the origin-destination pair composed by emerging market bonds (EMBI index) representing a flight-to-quality origin and US government securities (ITRROV index), representing a destination where the capital flies to. This is a legacy choice as emerging markets represent a special topic of interest for the authors. Being based on assets total returns dynamics, our approach could be applied to diverse origin-destination pairs on global, regional or country scale. The proposed framework is not limited to fixed income securities and could be applied to stocks, forex, precious metals and other types of investments. 
As we evidence by examining the typology of 133 identified flights-to-quality, the interrelation of interest rate and credit risk differs between expansion and contraction phases of the business cycle. Our study suggests that the concept of isolated interest rate risk management should be replaced by the advanced concept of downside risk management (Sortino 2001). The lessons learnt out of the global financial crisis of 2008-2009 corroborate with the conclusions arising from our research covering the wider time interval 1998-2010, that flight-to-quality events are characterized, on the one hand, by a downward tendency in interest rate dynamics, and, on the other hand, by simultaneous deterioration of the average creditworthiness of debt issuers belonging to all groups: banks, corporates and sovereigns.

For example, the second half of the year 2008 is a major flight-to-quality event, with capital flying from risky to safe assets, augmenting credit risk spreads of the former and diminishing the yields of the latter. All the 133 identified flights-to-quality identified along 1998-2010 show that such situations are not rare; instead, they are common as crashes and recessions usually coincide with diminishing interest rate dynamics.

Taking that example, we examine the effects of widely used practices of interest rate risk hedging by pay-fixed receive-float IRS, usually contracted to mitigate negative outcomes of uptrends in interest rates without due analyses of the macroeconomic conjuncture and interrelations between different types of financial risk. IRS derivatives are used to swap interest rates with counterparties, with the notional value being some agreed on amount, that the interest rate payments would be based on. Hence, it is easy to make a simple estimate of the total amount of losses suffered by the counterparties, who swap fixed-rate payables for float-rate receivables, when instead of an expected increase interest rates suddenly commence to decrease. For this sake, we consider the dynamics of the midterm risk-free interest rate described by the US generic government 5 -year yield (further on referred to by its Bloomberg ticker USGG5YR). By the end of June 2008, the value of the respective yield was $3.33 \%$ while in the middle of December 2008 the same yield dropped to the value of $1.25 \%$. Considering such dynamics, a payfixed receive-float swap of $\$ 100$ million notional with 5 -year maturity contracted at par value in June 2008 by the end of 2008 would have resulted in roughly
$\$ 10$ million of losses, i.e. about $10 \%$ of a notional of the initial contract. The subjacent back-on-theenvelope math is a $2 \%$ drop times the $\$ 100$ million notional times 5 years to suffer this drop into the future. For more detailed calculations, it would be necessary to analyse the dynamics of the IRS provoked losses, calculating them as a sum of net payments performed to a date and the IRS market value at that date.

Secondly, we compare the USGG5YR dynamics to the dynamics of the CDS spread. CDS spread is described by the investment grade index composed by 125 US single-name CDS, referred to as CDX $I G$ credit default index. Its behaviour was quite opposite to the behaviour of the value of the IRS, contracted prior to the global financial crisis. For instance, within the historical records of the 5-year series of the CDX IG index, the highest value is observed around December 2008. Thus, purchasing a credit default protection based on $C D X I G$ index would result exactly in opposite to the considered IRS outcome, i.e. major gains between June 2008 and December 2008. From the levels below 50 basis points over the 2005, 2006 and the first half of 2007, the CDX IG 5-year spreads had peaked at the time of the Bearn Sterns collapse at 190 bps and had lowered themselves to levels between 100 and 150 bps in June 2008. Later on, after the Lehman Brothers bankruptcy, the CDX IG 5-year spreads had newly peaked at all times highs in December 2008, reaching the 275 bps mark. Thus, the value gain for the contracted in June 2008 CDS protection of $\$ 100$ million notional over $C D X \quad I G$ index would approximately amount to $\$ 7.5$ million. The subjacent back-on-the-envelope math is $150 \mathrm{bps}$ times $\$ 100$ million notional times 5 years of residual maturity.

These analyses suggest that there is a natural hedge between holding a pay-fixed receive-float IRS and a CDS protection. Thus, buying CDS potentially could be used as a hedging tool for pay-fixed receive-float IRS. The opposite is also valid. Selling CDS could be used as a hedge for the pay-float receive-fixed IRS. These examples of hedge strategies allowing for downside risk mitigation demonstrate the potential importance of the correct determination of flight-to-quality windows achievable by our automated approach. 
On the other hand, the correct identification of flight-to-quality should be observed while contracting pay-fixed receive-float IRS to hedge the interest rate risk of the portfolios. As could be inferred from flight-to-quality characteristics, the best timing to contract additional IRS is the date after the end of flight-to-quality. Even in this case, the concept of the isolated interest rate risk management ought to be rethought in terms of a downside risk management of jointly considered interest rate and credit risk impacts.

Our findings urge for deeper assessing risk integration results and focusing on diversification versus compounding effects for further discussion between banking industry and financial markets regulators. Examining rules for asset sensitivity or nonsensitivity to interest rate and providing an integrated treatment of interest rate and credit risk potentially allows for optimizing bank economic and regulatory capital and, thus, acceleration of economic growth. Especially useful, in this sense, could be stress tests based on flight-to-quality frame windows that were presented in our study.

\section{Conclusions}

This study proposes a total return-based framework to analyse flight-to-quality events, based on three components.

The first component is the general definition of flight-to-quality event, based on the comparative behaviour of safe and risky assets total returns. The definition is applicable to diverse asset classes and is not restricted only to the fixed-income originationdestination pairs of securities, mutually affected during flight-to-quality episodes. Thus, the performed elaboration of general definition of flight-to-quality in terms of the total returns instead of the differential spread, for instance, is a relevant contribution to the literature as there is an absence of a universal definition of the phenomenon while many researches have been dedicated to the study these phenomena.

The second component is the development of a typological classification of flights-to-quality. In accordance with the proposed typology, two types of flight-to-quality are distinguished. The downturn type 1, which is the most common type for deteriorating economic conditions, crisis phases and also turning points, leads to a decrease of the risk-free interest rate. On the other hand, upturn type 2, which is rather rare, is accompanied by a decrease in the safe asset performance due to the expansion of the overall economic activity. The downturn type 1 flight-to-quality events are then segregated into the two subtypes. The subtype 1A Downturn flight-toquality phenomena, with decaying total returns of the risky assets, are the most frequent episodes under a slowdown of the economy. The important insight of this research is the attribution of the subtype 1B Start-of-the-downturn flight-to-quality phenomena, characterized by the increase in total returns of both safe and risky assets, to the initial worries of investors in respect to the future changes in the course of the economy. Therefore, these events can be interpreted as indicators of upcoming turning points, in general, and, in particular, as warnings of an approaching slowdown in economic activity.

The third component of the framework is related to the automated identification algorithm. The objective of the proposed diagnostics methodology is to detect the time windows and the strength of the occurred flights-to-quality within the considered historical period. The proposed methodology represents an important progress as it gives a new insight into the analysis of circumstances under which flights-to-quality occur, allowing automatic detection of the initial and final dates of the studied episodes.

The total return-based framework is applied to the analyses of investment flights out of emerging market securities towards US Treasury bonds within 19982010. In total, 133 flight-to-quality events are identified, measured and classified. Statistical analyses allowed us to segregate the homogeneous group of the most impactful flights-to-quality and verify that in fact they correspond to the major turmoil affecting emerging markets. From the typological point of view, all the diagnosed flights-to-quality are put in the context of the economic environment depending on their types. This study suggests the validity of the economic interpretation ascribed to the two types and two subtypes of flight-to-quality.

Our research also indicates that such a framework can be a useful tool for future flight-to-quality studies. The main reasons supporting this statement are the following. First, our framework includes an advanced typology that helps us to 
distinguish between different kinds of flight-toquality episodes. Second, it has an innovative measurement technique for identifying and tracing those episodes that could be used in other economic contexts. Third, it offers an important insight on the changing relationship between rates of return and credit risk.

Our research highlights how financial and banking institutions could develop hedge strategies against downside risks, related to interdependence of credit and interest rate risks. Practical approaches would be elaborations of stress tests based on delimited in our research flight-to-quality windows. The interaction between these risks within the flight-to-quality time intervals during diverse phases of business cycle potentially allows banks and financial institutions to optimize their economic and regulatory capital, thus accelerating economy and augmenting social welfare.

\section{Disclosure statement}

No potential conflict of interest was reported by the authors.

\section{Funding}

This work was supported by the Fundação para a Ciência e Tecnologia (FCT).

\section{ORCID}

Mariya Gubareva (D) http://orcid.org/0000-0001-6829-7021

Maria Rosa Borges (D) http://orcid.org/0000-0001-5340-471X

\section{References}

Alessandri, P., and M. Drehmann. 2010. "An Economic Capital Model Integrating Credit and Interest Rate Risk in the Banking Book." Journal of Banking and Finance 34 (4): 730-742.

Barkbu, B., B. Eichengreen, and A. Mody. 2012. "Financial Crises and the Multilateral Response: What the Historical Record Shows." Journal of International Economics 88 (2): 422-435.

Baur, D., and B. Lucey. 2009. "Flights and Contagion - an Empirical Analysis of Stock-Bond Correlations." Journal of Financial Stability 5 (4): 339-352.

Beber, A., M. Brandt, and K. Kavajecz. 2009. "Flight-toQuality or Flight-to-Liquidity? Evidence from the
Euro-Area Bond Market.” Review of Financial Studies 22 (3): 925-957.

Bernanke, B., M. Gertler, and S. Gilchrist. 1996. "The Financial Accelerator and the Flight-to-Quality." The Review of Economics and Statistics 78 (1): 1-15.

Black, F. 1970. Fundamentals of Liquidity. Internal Memo, Graduated School of Business, University of Chicago. https://speculativematerialism.files.wordpress.com/2013/ 07/fischer-black-fundamentals-of-liquidity-1970.pdf

Blinder, A., and M. Zandi. 2010. "How the Great Recession was brought to an End." Working Paper, Princeton University.

Bonfim, D., and C. Soares. 2013. "Is there a Risk-Taking Channel of Monetary Policy in Portugal?" Economic Bulletin and Financial Stability Report Articles, Bank of Portugal.

Briere, M., A. Chapelle, and A. Szafarz. 2012. "No Contagion, Only Globalization and Flight-to-Quality." Journal of International Money and Finance 31 (6): 1729-1744.

Brunnermeier, M., and L. Pedersen. 2009. "Market Liquidity and Funding Liquidity." Review of Financial Studies 22 (6): 2201-2238.

Bunda, I., J. Hamann, and S. Lall. 2009. "Correlations in Emerging Market Bonds: The Role of Local and Global Factors." Emerging Markets Review 10 (2): 67-96. doi:10.1016/j.ememar.2009.02.003.

Caballero, R., and P. Kurlat. 2008. "Flight-to-Quality and Bailouts: Policy Remarks and a Literature Review." Working paper No. 08-21, MIT Department of Economics.

Chabot, B. 2014. "Is there a Trade-Off between Low Bond Risk Premiums and Financial Stability?" Chicago Fed Letter 325. https://www.fedinprint.org/items/fedhle/ 00012.html

Chen, R., X. Cheng, and L. Wu. 2013. "Dynamic Interactions between Interest-Rate and Credit Risk: Theory and Evidence on the Credit Default Swap Term Structure." Review of Finance 17 (1): 403-441.

Goyenko, R., and A. Ukhov. 2009. "Stock and Bond Market Liquidity: A Long-Run Empirical Analysis." Journal of Financial and Quantitative Analysis 44 (1): 189-212.

Gubareva, M., and M. Borges. 2013 "Typological Classification, Diagnostics, and Measurement of FlightsTo-Quality." Working Paper No. 15/2013/DE/UECE. ISEG/ , University of Lisbon.

Guerrieri, V., and R. Shimer. 2014. "Dynamic Adverse Selection: A Theory of Illiquidity, Fire Sales, and FlightTo-Quality." The American Economic Review 104 (7): 1875-1908.

Inci, A., H. Li, and J. McCarthy. 2011. "Measuring Flight-toQuality: A Local Correlation Analysis." Review of Accounting and Finance 10 (1): 69-87.

Jarrow, R., and S. Turnbull. 2000. "The Intersection of Market and Credit Risk." Journal of Banking and Finance 24 (1-2): 271-299. 
Jones, E. 2012. "Eurobonds, Flight-to-Quality, and TARGET2 Imbalances." European Policy Analysis 4: 1-12.

Kiesel, R., W. Perraudin, and A. Taylor. 2002. "Credit and Interest Rate Risk." In Risk Management: Value at Risk and Beyond, edited by Dempster, M. and H. Moffatt, 129-144. Cambridge: Cambridge University Press.

Lei, Q., and H. Wang. 2012. "Flight-to-Liquidity due to Heterogeneity in Investment Horizon." China Finance Review International 2 (4): 316-350.

Mandelbrot, B., and R. Hudson. 2004. The (Mis) Behavior of Markets. London: Profile.

Naes, R., J. Skjeltorp, and B. Odegaard. 2011. "Stock Market Liquidity and the Business Cycle." Journal of Finance 66 (1): 139-176.

Pagano, M., and T. Strother. 2013. "Risk, Uncertainty, and the Perceived Threat of Terrorist Attacks: Evidence of Flight-To-Quality.” Quarterly Journal of Finance 3 (2): $1-25$

Psillaki, M., and K. Eleftheriou. 2014. "Trade Credit, Bank Credit, and Flight-to-Quality: Evidence from French Smes." Journal of Small Business Management, Article first published online: 20 FEB 2014. doi:10.1111/ jsbm.12106.

Rösch, C., and C. Kaserer. 2013. "Market Liquidity in the Financial Crisis: The Role of Liquidity Commonality and Flight-To-Quality." Journal of Banking and Finance 37 (7): 2284-2302.

Sortino, F. 2001. "From Alpha to Omega." In Managing Downside Risk in Financial Markets: Theory, Practice and Implementation, edited by Sortino, F. and S. Satchell, 3-25. Oxford: Reed Educational and Professional Publishing. 